\title{
Spiritual character traits and leadership in the school workplace: An exploration of the relationship between spirituality and school leadership in some private and religiously affiliated schools in South Africa
}

\author{
Authors: \\ Jaco S. Dreyer ${ }^{1}$ \\ Chris A.M. Hermans ${ }^{1,2}$ \\ Affiliations: \\ ${ }^{1}$ Department of Philosophy, \\ Practical and Systematic \\ Theology, University of South \\ Africa, South Africa \\ ${ }^{2}$ Department of Empirical \\ and Practical Religious \\ Studies, Radboud University \\ Nijmegen, The Netherlands \\ Correspondence to: \\ Jaco Dreyer \\ Email: \\ dreyejs@unisa.ac.za \\ Postal address: \\ PO Box 392, Pretoria 0003, \\ South Africa \\ Dates: \\ Received: 17 Aug. 2013 \\ Accepted: 19 Nov. 2013 \\ Published: 07 Aug. 2014 \\ How to cite this article: \\ Dreyer, J.S. \& Hermans, \\ C.A.M., 2014, 'Spiritual \\ character traits and \\ leadership in the school \\ workplace: An exploration \\ of the relationship between \\ spirituality and school \\ leadership in some private \\ and religiously affiliated \\ schools in South Africa', \\ Koers - Bulletin for Christian \\ Scholarship 79(2), Art. \\ \#2136, 9 pages. http:// \\ dx.doi.org/10.4102/koers. \\ v79i2. 2136

\section{Copyright:} \\ C 2014. The Authors. \\ Licensee: AOSIS \\ OpenJournals. This work \\ is licensed under the \\ Creative Commons \\ Attribution License.

\section{Read online:}

The South African educational system is in a crisis. This situation places huge demands on school principals and school management teams, and raises many theoretical and empirical questions. Transformational leadership is needed to deal with these challenges and complexities. Not all school leaders show the same level of transformational leadership. Some leaders conform more to other leadership styles. The aim of this article is to explore the relation between spiritual character traits and leadership styles from a theoretical and empirical perspective. The theoretical part focuses on the conceptualisation of leadership (styles) and spirituality. The empirical research consists of a web-based survey conducted in some private and religiously affiliated schools in South Africa in 2011-2012. The Multifactor Leadership Questionnaire (MLQ) and Cloninger's shortened Temperament and Character Inventory (TCI-140) were used to measure leadership styles and spiritual traits respectively. Statistical procedures included confirmatory factor analysis, correlation (Pearson rho) and regression analysis. Key findings are that leaders of private schools in South Africa mostly conform to a transformative leadership style, disagree with corrective leadership and strongly disagree with passive-avoidant leadership. Regarding the spiritual character traits they agree with self-transcendence and strongly agree with self-directedness. Spiritual character traits are strong predictors for transformational and passive-avoidant leadership. Higher levels of self-transcendence and self-directedness are strong predictors for transformational leadership. Our research suggests that traditional religious variables are less important as predictors of leadership style than spiritual character traits.

Spirituele karaktereienskappe en leierskap in die skool as werkplek: 'n Ondersoek na die verband tussen spiritualiteit en skoolleierskap in ' $n$ aantal privaat- en godsdiensgeaffilieerde skole in Suid-Afrika. Die Suid-Afrikaanse onderwysstelsel is in 'n krisis. Hierdie situasie stel skoolhoofde en skoolbestuursliggame bloot aan geweldige eise, en gee aanleiding tot verskeie teoretiese en empiriese vrae. Transformatiewe leierskap is nodig om hierdie uitdaging en kompleksiteite die hoof te bied. Skoolleiers verskil egter ten opsigte van transformatiewe leierskap, met sommige leiers wat andersoortige leierskapstyle het. Die doel met hierdie artikel is om die verband tussen spirituele karaktereienskappe en leierskapstyle teoreties en empiries te ondersoek. Die teoretiese gedeelte gee aandag aan die konseptualisering van leierskap(-style) en spiritualiteit. Die empiriese navorsing maak gebruik van die resultate van 'n web-gebaseerde ondersoek wat onder leiers van 'n aantal privaat- en godsdiensgeaffilieerde skole in Suid-Afrika in 2011-2012 onderneem is. Die Multifaktor-leierskapvraelys (MLQ) en Cloninger se verkorte weergawe van die Temperament- en Karakteropname (TCI140 ) is gebruik om onderskeidelik leierskapstyl en spirituele karaktereienskappe te meet. Die statistiese ontledings sluit bevestigende faktoranalise, korrelasie (Pearson se rho) en regressieanalise in. Die vernaamste bevindinge is dat leiers van privaatskole in Suid-Afrika meestal saamstem met ' $n$ transformatiewe leierskapstyl, 'n korrektiewe leierskapstyl verwerp, en glad nie saamstem met 'n passief-vermydende leierskapstyl nie. Met betrekking tot die spirituele karaktereienskappe stem die leiers saam met self-transendensie en veral met selfgedrewenheid. Dit blyk dat spirituele karaktereienskappe sterk voorspellers is vir transformatiewe leierskap. Die navorsing suggereer verder dat tradisionele godsdiensveranderlikes minder belangrike voorspellers is vir leierskapstyl as spirituele karaktereienskappe.

\section{Introduction}

The South African educational system seems to be in constant crisis, despite high state expenditure on education and numerous education policies. Almost two decades after the major socio-political 
changes in the first half of the 1990s, which transformed South Africa into a democratic country, we still witness an education crisis in South Africa. This crisis includes poorly trained teachers, low teacher morale, low productivity, high pupil dropout and failure rates, overcrowded and underresourced school facilities, school violence and criminality, continuing racism and so forth.

One response to this education crisis is to focus on the importance of effective and ethical leadership in schools. School leadership in such a crisis situation obviously places huge demands on school principals and school management teams. This raises many theoretical and empirical questions. What type of leadership is the most appropriate to deal with the challenges and complexities? How do school leaders meet these leadership challenges? What type of leadership do they practise? These are all important questions, but from a religious perspective we are particularly interested in the possible role that the religious or spiritual identities of leaders play regarding their leadership in the school workplace.

The aim of this article is to explore the relation between spirituality and school leadership from a theoretical and empirical perspective. To do so, we first describe the theoretical framework for the research. In a context like South Africa, where the educational system is in crisis, we need school leaders who bring changes that provide new possibilities, changing the face of schools. The style of leadership best oriented towards an emerging future is transformational leadership. Not all school leaders have a strong focus on this type of leadership. The presumption is that the personal identity of the leader is a strong predictor of this type of leadership (Hermans \& Koerts 2013; House \& Howell 1992). In this article, we investigate this presumption by studying the relationship between spiritual character traits and leadership styles. This is followed by a description of the research design, the results of our empirical research and a summary and conclusion. The empirical research that we report here forms part of a collaborative research project on 'Spirituality and Leadership among school leaders in South Africa' conducted by the University of South Africa in collaboration with the Radboud University, Nijmegen.

\section{Theoretical framework}

In this section we give a short exposition of the two key concepts, namely, leadership styles and spiritual character traits. A more extensive discussion of the theoretical framework is found in the work of Hermans and Koerts (2013).

\section{Leadership styles}

The type of educational leadership required has changed in recent years. Hallinger (2003) describes the change from an instructional type of leadership to transformational leadership as the most suitable type of leadership for school principals. This transformational type of leadership is referred to as the new-genre leadership. It emerged in the 1980s and has become known as charismatic leadership, transformational leadership or authentic leadership (see Avolio, Walumbwa \& Weber 2009; Yukl 2006:248ff.). The theory of transformational leadership by Bass (1985) generated much empirical research and conceptual development, and it is this theory that we take as reference for our conceptualisation of leadership.

Bass (1985:27) coined the concept transformational leadership in the mid-1980s. He was dissatisfied with the dominant leadership theories at that time, which regarded leadership as the result of 'an exchange process: a transaction in which followers' needs are met if their performance measures up to their explicit or implicit contracts with their leader'. The goal of transformational leadership was a kind of higher order improvement, which included three types of transformational behaviour: idealised influence (i.e. arousing strong followers' emotions and identification with the leader), intellectual stimulation (i.e. awareness of problems and their solution) and individualised consideration (i.e. empowerment of followers) (Bass 1985:34-38). Later versions of this theory added inspirational motivation, which includes communicating an appealing vision and using symbols to focus subordinate effort (for the development see Antonakis, Avolio \& Sivasubramaniam 2003; Avolio \& Bass 2004; Avolio, Walumbwa \& Weber 2009; Bass \& Avolio 1990, 1993). Antonakis et al. (2003) give the following concise description of the dimensions of transformational leadership:

1. Idealised influence (attributed) refers to the socialised charisma of the leader, whether the leader is perceived as being confident and powerful, and whether the leader is viewed as focusing on higher-order ideals and ethics.

2. Idealised influence (behaviour) refers to charismatic actions of the leader that are centered on values, beliefs, and a sense of mission.

3. Inspirational motivation refers to the ways leaders energise their followers by viewing the future with optimism, stressing ambitious goals, projecting an idealised vision, and communicating to followers that the vision is achievable.

4. Intellectual stimulation refers to leader actions that appeal to followers' sense of logic and analysis by challenging followers to think creatively and find solutions to difficult problems

5. Individualised consideration refers to leader behaviour that contributes to follower satisfaction by advising, supporting, and paying attention to the individual needs of followers, and thus allowing them to develop and selfactualise. (Antonakis et al. 2003:264-265).

Two comments are appropriate here. Firstly, in the measurement of the MLQ the dimensions of idealised influence (attributed) and idealised influence (behaviour) are combined in one dimension, namely idealised influence ${ }^{1}$. Secondly, we added the dimension of trust as a dimension of transformational leadership. Transformational leaders are trustworthy; they keep their word.

1.The other dimensions are: individualised consideration, intellectual stimulation and inspirational motivation. 
Why is transformational leadership so effective? Yukl (2006:264) suggests that the process of internalisation could explain why transformational leadership works. According to Avolio et al. (2009), it is because transformational leaders:

raise followers' aspirations and activate their higher order values (e.g., altruism) such that followers identify with the leader and his or her mission/vision, feel better about their work, and then work to perform beyond simple transactions and base expectations. (p. 428)

Bass and Avolio did not only focus on transformational leadership. They also attempted to construct a comprehensive model of leadership. Next to transformational leadership, Avolio and Bass (2004) defined two other types of leadership, namely transactional leadership (including contingent reward and active management-by-exception) and passive-avoidant leadership (laissez faire and passive management-by-exception) (Avolio \& Bass 2004). These three leadership styles form the conceptual basis of the Multifactor Leadership Questionnaire (MLQ) (Avolio \& Bass 2004) that we used in our research.

\section{Spiritual character traits}

There is a growing interest in the role of spirituality in the workplace (Geh \& Tan 2009). Geh and Tan refer to Giacalone and Jurkiewicz's (2003) Handbook of workplace spirituality and organizational performance in which the authors identified three thematic areas to explain the phenomenon of workplace spirituality. Firstly, people tend to rely on spirituality in order to cope with the tensions caused by the rapidly changing nature of the world of work. Secondly, the role of values in the world of work has, in recent years, received more recognition. People do not only work for material gain, but see work as part of their self-actualisation. There is also a greater emphasis on corporate responsibility and ethical business practices in recent years. Thirdly, there seems to be a general increase of interest in spirituality.

One of the main problems for workplace spirituality research is the lack of consensus regarding the notion of spirituality. Following the psychiatrist Cloninger (2007:740), for the purpose of this research we regard spirituality as a search for - and a means of reaching - something beyond human existence, creating a sense of connectedness with the world and with the unifying source of all life. It is thus an expression of people's profound need for coherent meaning, love and happiness. The need to create coherent meaning (in terms of wholeness, fullness, ultimacy) is inherent for our very existence as human beings. A human being is the only living organism that can experience conflict with itself (McNamara 2009:32-42). This experience can come in a cognitive mode (not knowing one's true self, experiencing discordance in past and present images of oneself); an affective mode (feeling bad, without hope or happiness); or a volitional mode (not having the right will, doing what one understands as being wrong). From a psychobiological point of view, this is an emotional conflict (Cloninger 2004, 2007, 2008). Emotional drives (like harm avoidance or reward dependence) demand immediate gratification, and competing drives conflict with one another (like risk-taking versus harm avoidance). These conflicts cannot be resolved on the emotional level, but we need to develop character traits that regulate these conflicts. Regulation demands self-awareness ('Why am I so upset in this situation?') and discernment ('How can this conflict be resolved?'). According to Cloninger (2007:742), character develops through growth in self-awareness as we try to find meaning and satisfaction by acquiring ever-more coherent perspectives on our lives. Following Cloninger, we can identify three character traits that help us to grow in discernment to reach human fullness (e.g. beyond the divided self), namely, self-directedness, cooperativeness and self-transcendence. These three traits refer to the relationship with oneself, others and what is beyond. The trait of self-directedness is characterised by responsibility and purposefulness (versus blaming and aimlessness), cooperativeness, tolerance and kindness (versus prejudice and revengefulness), and self-transcendence by intuitiveness, openness for a unifying reality and being self-forgetful (versus being conventional and sceptical). According to Cloninger (2007:741), these character traits represent the mental expression of the virtues of hope (i.e. self-directedness), love (i.e. cooperativeness) and faith (i.e. self-transcendence). ${ }^{2}$ Developing good character traits is the psychological equivalent of becoming virtuous (in an ethical sense). The development of character traits is a lifelong process with different stages, each one representing a different level of selfawareness towards human fulfilment as a kind of effortlessly calm, impartial, wise and loving, unified being.

This spiritual perspective allows us to grow in self-awareness so that we can see that we often live our lives in division, split between contradictory desires that create conflict and dissatisfaction. Growing in awareness of this division will help a person to transcend his or her problems and to rediscover a sense of unity (Cloninger 2007:742).

\section{Research design}

In this section we first formulate our research questions. Next we describe the sampling procedure and data collection, the measuring instruments and, lastly, the design of the data analysis.

\section{Research questions}

We formulated the following research questions:

1. To what extent do school leaders in private and religiously affiliated schools in South Africa agree with different styles of leadership?

2. To what extent do school leaders in private and religiously affiliated schools in South Africa agree with different spiritual character traits?

3. Which personal, religious and professional characteristics and spiritual character traits are associated with the agreement of these school leaders with different styles of leadership?

2.See Hermans and Koerts (2013) for a more detailed discussion of the relationship between spirituality and character traits. 
4. To what extent do spiritual character traits predict styles of leadership, whilst controlling for personal, professional and religious characteristics?

\section{Sampling and data collection}

Owing to the difficulty in obtaining permission to conduct research in public schools, we decided to do this research in some private and religiously affiliated schools. We opted for a non-probability (convenience) sample of school leaders (principals, vice-principals and those leaders involved in the strategic management of the school) from selected private schools to participate in our web-based survey. We initially (October 2011) approached primary and secondary Catholic private schools affiliated to the Catholic Institution of Education in Gauteng and Western Cape to participate in our web-based survey. ${ }^{3}$ Thirty of the 55 schools in Gauteng and 10 of the 44 schools in the Western Cape responded positively to our request. Owing to the low numbers, we decided to extend the invitation to participate to Catholic private schools in two other provinces (KwaZulu-Natal and the Eastern Cape). Five of the 12 schools in KwaZulu-Natal and 9 of the 49 schools in the Eastern Cape participated. We also invited public Catholic schools not affiliated to the Catholic Institution of Education to participate. Twelve of the 172 schools that we contacted telephonically indicated their willingness to participate in the survey. In May 2012 we invited schools affiliated with the Association of Christian Schools Institute (ACSI) to participate. Eleven of the 61 schools throughout South Africa responded positively. Lastly, we invited schools associated with the Independent Schools Association South Africa (ISASA) in July 2012 to participate. Thirty-three of these schools, spread throughout the country, responded positively.

The online questionnaire was completed anonymously. The web-based nature of the survey caused some problems as the survey had to be completed in one sitting. Many participants only completed the first part of the questionnaire; therefore, these responses could not be used. Altogether, 132 questionnaires were completed in full and could be used in our data analysis. Forty percent $(n=53)$ of the participants were male and $60 \%(n=79)$ female. Sixty percent $(n=79)$ of the participants indicated that they were either the principal or vice-principal of the school, $10 \%(n=13)$ a subject head, $16 \%(n=23)$ a member of the school management team, and $15 \%(n=19)$ either the religious education coordinator or serving in another leadership capacity.

The majority of our participants were from primary schools $(41 \% ; n=54)$. A third $(33 \% ; n=43)$ of these leaders were from a combined primary and secondary school, and about a quarter $(24 \% ; n=32)$ from a secondary school. Only one respondent from a special education school participated in this survey. More than half $(58 \% ; n=77)$ of the respondents were from Catholic schools, with a further 39\% $(n=51)$ from other Christian schools. Only four participants $(3 \%$ indicated that the religious affiliation of their schools was

3.We thank Ms Glenda Dames for her assistance with the data collection. Withou her perseverance, creativity and dedication, we could not have completed this process. another religion. Regarding geographical representation, it is important to note that more than half $(54 \% ; n=71)$ of the respondents were from Gauteng. The Western Cape, Eastern Cape and KwaZulu-Natal, with $17 \%(n=22), 15 \%(n=20)$ and $8 \%(n=10)$ respectively, were also fairly well represented. The other five provinces had between none and two per cent representation in our sample. Finally, the majority of the schools asked school fees of more than R20 000 per child per year $(62 \%) ; 12 \%$ of the schools asked relatively low school fees of R5000 or less a year; and the schools in the rest of our sample $(36 \%)$ charged something in between.

\section{Measuring instruments}

We used a validated instrument to measure types of school leadership, namely, the Short version (5X Short; 45 items) of the Multifactor Leadership Questionnaire (MLQ) developed by Avolio and Bass (2004). This questionnaire assesses three leadership styles, namely, transformational, transactional and passive/avoidant. The four main dimensions of a transformational leadership style assessed by the MLQ are the following:

- Idealised influence: This dimension indicates whether you have earned subordinates' trust, maintain their faith and respect, show dedication to them, appeal to their hopes and dreams, and act as their role model.

- Inspirational motivation: This measures the degree to which you provide a vision, use appropriate symbols and images to help others focus on their work, and try to make others feel their work is significant.

- Intellectual stimulation: This shows the degree to which you encourage others to be creative in looking at old problems in new ways, create an environment that is tolerant of seemingly extreme positions, and nurture people to question their own values and beliefs and those of the organisation.

- Individualised consideration: This indicates the degree to which you show interest in others' well-being, assign projects individually, and pay attention to those who seem less involved in the group.

Hermans added the dimension of trust to these four dimensions of transformational leadership (Hermans \& Koerts 2013). This dimension indicates the degree to which you are reliable in keeping your promises. ${ }^{4}$

The two dimensions of a transactional leadership style assessed by the MLQ are as follows:

- Contingent reward: This shows the degree to which you tell others what to do in order to be rewarded, emphasise what you expect from them, and recognise their accomplishments.

- Management-by-exception (active): This assesses whether you tell others the job requirements, are contented with standard performance, and are a believer in 'if it ain't broke, don't fix it'.

4.The three items added are 'I need to be trusted, keep my word', 'I need to be reliable in keeping my promises' and 'I need to act in such a way that others can entrust themselves to me'. 
The third leadership style, namely passive-avoidant, also has two dimensions:

- Laissez-faire: This dimension measures whether you require little of others, are content to let things ride, and let others do their own thing.

- Management-by-exception (passive): This assesses whether you tell others the job requirements, are content with standard performance, and are a believer in 'if it ain't broke, don't fix it.'

We used the character scales ${ }^{5}$ of the shortened Temperament and Character Inventory (TCI-140) developed by Cloninger, Svrakic and Przybeck (1993) to measure the dimension of spirituality in terms of character or spiritual traits. The development of well-being and the regulation of potential conflicts amongst pre-logical emotional drives in self-aware consciousness, involve three rational cognitive processes of foresight, judgment and insight, which (it is hypothesised) the three character traits of self-directedness (SD) (not driven by external forces but having an inner compass), cooperativeness (C) (getting along with others) and selftranscendence (ST) (openness to the possible) are thought to measure.

Each of these 'rational' processes has modules for adapting to each type of situation or layer of personality, which are supposed to be measured by character subscales. The self-directedness scale consists of five facets or subscales, namely, responsibility, purposefulness, resourcefulness, selfacceptance and congruent second nature. Self-directedness is hypothesised to measure the executive functions of foresight, as shown by a person being self-directed in the sexual plane (i.e. responsible), in the material plane (i.e. purposeful), in the emotional plane (i.e. cheerfully self-accepting), in the intellectual plane (i.e. resourceful), and in the spiritual plane (i.e. spontaneous, so that habits and intentions are congruent (Cloninger 2008:293).

Cooperativeness also consists of five facets or subscales, namely, social acceptance, empathy, helpfulness, compassion and pure-hearted conscience. Cooperativeness measures the legislative function of judgment, which involves making rules that allow us to get along with each other in a reasonable and flexible manner in each plane of our lives. Persons high in cooperativeness are assumed to identify with, accept and be tolerant of others.

The scale of self-transcendence consists of three facets or subscales, namely, self-forgetfulness (e.g. the experience of a loss of time and place), transpersonal identification (e.g. the experience of unity with all people, with everything in the world and with a spiritual power) and spiritual acceptance (e.g. the belief in wonder and extraordinary experiences). Self-transcendence measures the judicial function or depth of insight that allows us to know intuitively when our seeking, reward
dimensions. legislative rules apply in a particular situation. Individuals high in self-transcendence regard themselves as an integral part of the universe, and TCI items related to this domain assess experiences associated with meditative practice, spirituality and a sense of connectedness to all living things (Cloninger 2007:741).

We also included a number of background variables such as personal characteristics (e.g. age and gender), religious characteristics (e.g. strength of belief in God, frequency of personal prayers and frequency of church visits) and professional characteristics (e.g. leadership position and type of school).

\section{Design of analysis}

To answer the first and second question we executed a confirmatory factor analysis (Principle Axis Factoring or PAF) before calculating the mean. PAF analyses only the variance in the items that are shared with other items. It is generally considered best for exploring the underlying factors for theoretical purposes (Kim 2008). The MLQ is supposed to measure three types of leadership: transformational, transactional and passive-avoidant. Therefore, we used three factors as extraction criteria. For the measuring instrument of the second research question (TCI), factor analysis is always done on the facet scales and not the individual items (see Farmer \& Goldberg 2008). Before executing a confirmatory factor analysis (PAF), we check the internal validity of the facet scales (alpha). For the third research question we used Pearson rho. For the fourth research question we use a regression analysis design with two models. In the first model we used all personal, professional and religious characteristics that have a significant correlation with one of the types of leadership styles. In the second model we added to these characteristics all spiritual characteristics that have a significant correlation with this leadership style. If our theoretical presumptions were right, adding spiritual characteristics would decrease the predictive power of the personal, professional or religious characteristics or even make them non-significant.

\section{Results}

We now return to the research questions. The first question asks to what extent school leaders in private and religiously affiliated schools in South Africa agree with the different styles of leadership. The factor-analysis of the MLQ shows three factors with a good reliability (see Table 1-A1). The first factor contains all the theoretical aspects of transformational leadership: idealised influence (i.e. arousing strong followers' emotions and identification with the leader), intellectual stimulation (i.e. awareness of problems and their solution), individualised consideration (i.e. empowerment of followers), inspirational motivation (i.e. communicating an appealing mission) and trust (i.e. of the leader and followers). Our analysis also confirms the third type of leadership, namely, passive-avoidant leadership. However, with regard to transactional leadership all items for contingent reward were missing. Only the active management-by-exception 
dimension is retained in this factor. ${ }^{6}$ We labelled this as corrective leadership as this leadership style only reacts to failures or errors of the followers.

Answering our first research question, we see that there is strong agreement with transformative leadership (mean 4.35), disagreement with corrective leadership (mean 2.65) and a strong disagreement with passive-avoidant leadership (mean 1.84) (see Table 1). The school leaders in our sample are clearly in most agreement with a transformational leadership style.

Our second research question is: To what extent do school leaders in private and religiously affiliated schools in South Africa agree with different spiritual character traits? Our analysis of the internal consistency (see Table 2-A1) shows that the facets in the dimension of cooperativeness had a very low internal validity. We therefore decided not to continue with this dimension of the spiritual character traits. Regarding the other two dimensions (self-directedness and self-transcendence) we had to remove one facet scale in the dimension of self-directedness because of low communality (commonality $<.20$ ) in the factor analysis (PAF; see Table 1-A1). No significant correlation was found between the spiritual character traits of self-directedness and self-transcendence. We now answer our second research question. Our participants showed agreement with selftranscendence and strong agreement with self-directedness (see Table 2).

Which personal, religious and professional characteristics and spiritual character traits are associated with the different styles of leadership of these school leaders? From Table 3 we can see that a transformational leadership style has statistically significant correlations with gender, age, school fees (socio-economic status of the school), strength of belief in God, and the spiritual character traits of self-transcendence and self-directedness. A corrective leadership style only has significant correlations with obeying the rules of the church and self-directedness. The passive-avoidant leadership style has significant correlations with age, praying outside religious services and self-directedness.

The fourth and final research question is: To what extent, do spiritual character traits predict styles of leadership whilst controlling for personal, professional and religious characteristics? We start with the passive-avoidant leadership style. The first model contains all the personal, professional and religious characteristics that have a significant correlation with a passive-avoidant leadership style. The second model includes, in addition, all spiritual characteristics with a significant correlation with this leadership style.

From Table 4 we see that only two of the personal, professional and religious characteristics show a significant relation with

6.There are statistically significant correlations between a transformational leadership style and the two other leadership styles (passive-avoidant $r-.37 ; p<.01$; corrective $r .18 ; p<.05)$. No significant correlation was found between corrective and passive$r .18 ; p<.05)$. No signifi
avoidant leadership. a passive-avoidant leadership style, namely, age (older participants are less inclined to opt for a passive-avoidant leadership style) and frequency of praying outside meetings of the religious community (the more they pray, the less they favour a passive-avoidant leadership style). When the spiritual character traits are added in the second model, age still maintains a statistically significant predictor (although now only at $p<0.05$ ) of a passive-avoidant leadership style, but praying outside the religious community is no more statistically significant. The spiritual character trait of selfdirectedness is, however, a statistically significant predictor

TABLE 1: Descriptives of styles of leadership.

\begin{tabular}{lll}
\hline Leadership style & Mean & SD \\
\hline Transformational leadership & 4.35 & .45 \\
Corrective leadership & 2.65 & .85 \\
Passive-avoidant leadership & 1.84 & .69 \\
\hline
\end{tabular}

SD, standard deviation.

Scale from 1-5: 1, not at all; 2 , once in a while; 3 , sometimes; 4 , fairly often; 5 , frequently if not always

TABLE 2: Descriptives of spiritual characteristics.

\begin{tabular}{lll}
\hline Spiritual characteristics & Mean & SD \\
\hline Self-directedness & 1.11 & .16 \\
Self-transcendence & 1.34 & .16 \\
\hline
\end{tabular}

SD, standard deviation.

Scale from 1 (true) to 2 (false)

TABLE 3: Correlations (Pearson rho) between types of leadership and personal, professional, religious and spiritual characteristics.

\begin{tabular}{llll}
\hline $\begin{array}{l}\text { Types of leadership and } \\
\text { characteristics }\end{array}$ & F1 & F2 & F3 \\
\hline $\begin{array}{l}\text { Personal characteristics } \\
\text { Gender }\end{array}$ & $.24^{*}$ & - & - \\
Age & $.20^{*}$ & $-.26^{* *}$ & -
\end{tabular}

Professional characteristics

Leadership position

School fee

Religious characteristics

Reading holy scripture

Praying outside services

Church visit

Obeying rules of the church

19*

Religious salience

Strength of belief in God

Spiritual characteristics

Self-transcendence

Self-directedness

$.18^{*}$

F1, transformational leadership; F2, passive-avoidant leadership; F3, corrective leadership. *, Significant at $p<.05 ; * *$, Significant at $p<.01$

TABLE 4: Parameter estimates for the regression coefficients for passiveavoidant leadership ( $n=132$ ).

\begin{tabular}{lll}
\hline Variables & Model 1 $(\boldsymbol{\beta})$ & Model 2 $(\boldsymbol{\beta})$ \\
\hline Age & $-.24^{* *}$ & $-.18^{*}$ \\
Praying outside services & $-.18^{*}$ & -.05 \\
Self-directedness & - & $.46^{* *}$ \\
$R$-square & .10 & .29 \\
Adjusted $R$-square & .09 & .28 \\
\hline
\end{tabular}

$\beta$, beta.

*, Significant at $p<.05 ;^{* *}$, Significant at $p<.01$ 
of a passive-avoidant leadership style. Less self-directedness ${ }^{7}$ is clearly related to a passive-avoidant leadership style in our sample. This makes sense, as a leader with low selfdirectedness is probably more driven by external forces than inner convictions. Younger leaders probably have less experience, especially with handling critical incidents, and thus probably tend to opt for a more passive-avoidant leadership style.

Next we turn to a corrective leadership style. The first model contains all the personal, professional and religious characteristics that have a significant correlation with a corrective leadership style. In the second model we add to these characteristics all spiritual characteristics with a significant correlation with this leadership style (see Table 5).

In this sample of school leaders we find more agreement with corrective leadership amongst participants who agree that it is important to adhere to all rules and regulations of the church or religious community to which they belong. This statistically significant relationship with corrective leadership remains when the spiritual character traits are included in the second model. There is, however, no statistically significant relation between the preference for a corrective leadership style and the spiritual character traits. Less self-directedness seems to predict a preference for a corrective leadership style, but this is only a tendency as the beta-coefficient in this model is not significant at the $p<.05$ level. With regard to the preference for a corrective leadership style we can say that school leaders who focus on external authority (e.g. a church or religious community) and an uncritical following of rules, tend to prefer a corrective leadership style. In general, neither a spiritual perspective (as measured by self-transcendence and self-directedness) nor any other personal characteristics are an indication that any school leaders agree more with this type of leadership compared to other school leaders.

What is the situation regarding our third type of leadership, namely, transformational leadership? In the first model we find more agreement with transformational leadership amongst older school leaders, female leaders, and leaders of schools in more affluent areas (higher school fees). When we add the spiritual character traits (second model), we find that gender (female), school fees (schools in more affluent areas), stronger self-directedness and higher levels of selftranscendence are statistically significant predictors of agreement with transformational leadership in our research sample. Age is no longer a statistically significant predictor in the second model (see Table 6).

How can we account for these findings? A possible explanation from gender theory (Markus \& Oyserman 1989) is that 'female' is an indicator of a focus on relationships (otherdirectedness), and this other-directedness is at the core of transformational leadership. It is also possible that leaders of schools in more affluent areas tend to spend less time making ends meet and thus have more opportunities and time to focus on transformation issues. This possible explanation will, however, have to be explored in further research. The strong link between self-directedness and transformational

7.The scale for self-directedness is from 1 (true) to 2 (false). A higher score is thus indicative of less self-directedness. leadership can be explained by the fact that leaders with strong self-directedness are not driven by external forces, but an inner compass - a requirement for transformational leadership. Leaders with a higher level of self-transcendence are persons who can forget themselves, have a strong sense of connectedness with nature and other people, and are inclined to anticipate the unexpectable (magical thinking). Or, to put it differently, they are individuals with openness to all possibilities.

\section{Summary and discussion}

Our research amongst school leaders of some private and religiously affiliated schools in South Africa indicates that these school leaders mostly agree with a transformative leadership style, disagree with corrective leadership and strongly disagree with passive-avoidant leadership. Regarding spiritual character traits, they agree with selftranscendence and strongly agree with self-directedness. In this sample of school leaders we find a number of significant relations between a transformative leadership style and certain personal (gender - female, age - older), professional (socio-economic context of the school as indicated by the school fees) and religious (strength of belief in God) characteristics, and with spiritual characteristics (self-directedness and self-transcendence). There are three correlations with passive-avoidant leadership: age (younger leaders), (not) praying outside services, and (less) selfdirectedness. We observed only two significant correlations with corrective leadership: (more) obeying the rules of the Church, and (less) self-directedness.

Finally, we tested influence of spiritual characteristics whilst controlling for personal, professional and religious characteristics. Spiritual characteristics are indeed a strong predictor for two types of leadership, namely, transformational and passive-avoidant leadership. For transformational leadership, both a higher level of selftranscendence and a higher level of self-directedness are strong predictors. For passive-avoidant leadership, only

TABLE 5: Parameter estimates for the regression coefficients for corrective leadership $(n=132)$.

\begin{tabular}{lll}
\hline Variables & Model 1 $(\boldsymbol{\beta})$ & Model 2 $(\boldsymbol{\beta})$ \\
\hline Obeying rules of the church & $.19^{*}$ & $.19^{*}$ \\
Self-directedness & - & .15 \\
$R$-square & .04 & .05 \\
Adjusted $R$-square & .03 & .04 \\
\hline
\end{tabular}

$\beta$, beta.

*, Significant at $p<.05 ; * *$, Significant at $p<.01$

TABLE 6: Parameter estimates for the regression coefficients for transformational leadership $(n=132)$.

\begin{tabular}{lll}
\hline Variables & Model 1 $(\boldsymbol{\beta})$ & Model 2 $(\boldsymbol{\beta})$ \\
\hline Gender & $.20^{*}$ & $.20^{* *}$ \\
Age & $.17^{*}$ & .08 \\
School fees & $.20^{*}$ & $.16^{*}$ \\
Self-directedness & - & $-.30^{* *}$ \\
Self-transcendence & - & $-.30^{* *}$ \\
$R$-square & .14 & .33 \\
Adjusted $R$-square & .12 & .29 \\
\hline
\end{tabular}

Adjusted $R$-square

.12

$\beta$, beta.

*, Significant at $p<.05 ; * *$, Significant at $p<.01$ 
a lower level of self-directedness induces a higher level of this type of leadership. Our theoretical model, based on two spiritual characteristics and a number of personal, professional and religious characteristics, does not help us to understand which leaders agree more and which agree less with this type of leadership. Our model only explains $4 \%$ of the variance in scores for corrective leadership, which is hardly relevant theoretically speaking. There is a possibility that the spiritual trait of cooperativeness might influence this type of leadership, because it focuses on the other in terms of empathy, helpfulness, compassion and pure-hearted conscience. This might be a good predictor of lower levels of corrective leadership, but we were not able to measure this concept in a valid way. Future research is needed to test (i.e. falsify) this prediction. Another result that needs some explanation is the reason why self-directedness is the only predictor for passive-avoidant leadership, whilst both spiritual traits (self-directedness and self-transcendence) are strong predictors for transformative leadership. The reason for this could be the fact that transformative leadership involves an attitude towards the emerging future (in terms of a mission, vision, inspirational motivation and trust), whilst passive-avoidant leadership is about (the absence of) a reaction to the behaviour of other school members. It is not about the possible, but about the concrete and, therefore, is not influenced by self-transcendence. Here too we are cautious in our claims, because we do not know whether the spiritual traits of cooperativeness also influence both types of leadership. We need to test this in future research.

We controlled the influence of spiritual characteristics for personal, professional and religious characteristics. It is interesting that there are no religious characteristics (as incorporated in our theoretical model) that are significant predictors of leadership. The only exception is 'obeying the rules of the church', which predicts corrective leadership. Again, the level of explained variance here is so low that it is hardly theoretically relevant. This is an interesting finding, because it seems to suggest that religious characteristics are less important predictors of leadership than spiritual characteristics. There is an ongoing debate about the concept of spirituality, and this debate will probably continue for some time (Ammerman 2013; Geh \& Tan 2009; Giacalone \& Jurkiewicz 2003). What is theoretically very interesting, however, is that spiritual traits (as measured by the TCI) are far better predictors of leadership styles than the 'classical' religious characteristics. The spiritual traits of selftranscendence and self-directedness measure something different from the 'classical' religious characteristics, and what they do measure clearly influences the types of leadership (as measured by the MLQ). For us as researchers, this is a very promising outcome, regarding not only research on spirituality in the workplace, but also everyday religiosity or lived spirituality.

\section{Acknowledgements Competing interests}

The authors declare that they have no financial or personal relationship(s) that may have inappropriately influenced them in writing this article.

\section{Authors' contributions}

J.S.D (University of South Africa) was mainly responsible for the data collection, the writing of the first draft and the preparation of the manuscript for publication. C.A.M.H. (Radboud University Nijmegen and University of South Africa) was mainly responsible for the project design, theoretical framework and the statistical calculations. Both authors contributed substantially to the refinement of the first draft.

\section{References}

Ammerman, N.T., 2013, 'Spiritual but not religious? Beyond binary choices in the study of religion', Journal for the Scientific Study of Religion 52(2), 258-278. http://dx.doi.org/10.1111/jssr.12024

Antonakis, J., Avolio, B.J. \& Sivasubramaniam, N., 2003, 'Context and leadership: An examination of the nine-factor full-range leadership theory using the multifactor leadership questionnaire', The Leadership Quarterly 14(3), 261-295. http:// dx.doi.org/10.1016/S1048-9843(03)00030-4

Avolio, B.J. \& Bass, B.M., 2004, Multifactor leadership questionnaire: Third edition manual and sample set, Mind Garden, Redwood City.

Avolio, B.J., Walumbwa, F.O. \& Weber, T.J., 2009, 'Leadership: Current theories, research, and future directions', Annual Review of Psychology 60, 421-449. http://dx.doi.org/10.1146/annurev.psych.60.110707.163621, PMid:18651820

Bass, B.M., 1985, 'Leadership: Good, better, best', Organizational Dynamics 13(3), 1985, 26-40.

Bass, B.M. \& Avolio, B.J., 1990, 'Developing transformational leadership: 1992 and beyond', Journal of European Industrial Training 14, 2-72. http://dx.doi. org/10.1108/03090599010135122

Bass, B.M. \& Avolio, B.J., 1993, 'Transformational leadership: A response to critiques', in M.M. Chemers \& R. Ayman (eds.), Leadership theory and research: Perspectives and directions, pp. 49-80, Academic Press, New York.

Cloninger, C.R., 2004, Feeling good. The science of well-being, Oxford University Press, Oxford. PMCid:PMC1449823

Cloninger, C.R., 2007, 'Spirituality and the science of feeling good', Southern Medical Journal 100(7), 740-743. http://dx.doi.org/10.1097/SMJ.0b013e318070d177, PMid:17639764

Cloninger, C.R., 2008, 'The psychobiological theory of temperament and character: Comment on Farmer and Goldberg', Psychological Assessment 20(3), 292-299. http://dx.doi.org/10.1037/a0012933, PMid:18778165

Cloninger, C.R., Svrakic, D.M. \& Przybeck, T.R., 1993, 'A psychobiological model of temperament and character', Archives of General Psychiatry 50, 975-990. http:// temperament and character', Archives of General Psychiatry 50, $975-996$.
dx.doi.org/10.1001/archpsyc.1993.01820240059008, PMid:8250684

Farmer, R.F. \& Goldberg, L.R., 2008, 'A psychometric evaluation of the revised Temperament and Character Inventory (TCl-R) and the TCl-140', Psychological Assessment 20(3), 281-291. http://dx.doi.org/10.1037/a0012934, PMid:18778164

Geh, E. \& Tan, G., 2009, 'Towards an understanding of spirituality at work in a changing world: Managerial and research implications', The Journa of Management, Spirituality and Religion 6(4), 287-300. http://dx.doi. org/10.1080/14766080903290093

Giacalone, R.A. \& Jurkiewicz, C.L., 2003, Handbook of workplace spirituality and organizational performance, M.E. Sharpe, Armonk.

Hallinger, P., 2003, 'Leading educational change: reflections on the practice of instructional and transformational leadership', Cambridge Journal of Education 33(3), 329-352. http://dx.doi.org/10.1080/0305764032000122005

Hermans, C.A.M. \& Koerts, E., 2013, 'Towards a model of influence of spirituality on leadership: Empirical research of school leaders on Catholic schools in the Netherlands', Journal of Beliefs \& Values: Studies in Religion \& Education 34(2), 204-219. http://dx.doi.org/10.1080/13617672.2013.801685

House, R.J. \& Howell, J.A., 1992, 'Personality and charismatic leadership', The Leadership Quarterly 3(2), 81-108. http://dx.doi.org/10.1016/10489843(92)90028-E

Kim, H-J., 2008, 'Common factor analysis versus principal component analysis: Choice for symptom cluster research', Asian Nursing Research 2(1), 17-24. http://dx.doi. org/10.1016/S1976-1317(08)60025-0

Markus, H. \& Oyserman D., 1989, 'Gender and thought: the role of the self-concept', Gender and Thought: Psychological Perspectives, 100-127, viewed 03 August 2013, from http://sitemaker.umich.edu/culture.self/files/markus_oyserman_1989.pdf

McNamara, P., 2009, The neuroscience of religious experience, Cambridge University Press, Cambridge. http://dx.doi.org/10.1017/CBO9780511605529

Yukl, G., 2006, Leadership in organizations, 6th edn., Pearson Prentice Hall, Upper Saddle River. 


\section{Appendix 1}

TABLE 1-A1: Factor analysis of styles of leadership (principal axis factoring, varimax rotation; eigenvalue $>1$; factor loading $>.30)^{\text {a }}$.

\begin{tabular}{|c|c|c|c|}
\hline$\underline{\text { Styles of leadership }}$ & F1 & F2 & F3 \\
\hline Inspirational motivation & .71 & - & - \\
\hline Individual consideration & .67 & - & - \\
\hline Idealised influence & .65 & - & - \\
\hline Intellectual stimulation & - & .64 & - \\
\hline Intellectual stimulation & - & .63 & - \\
\hline Idealised influence & .63 & .44 & - \\
\hline Intellectual stimulation & - & .62 & - \\
\hline Intellectual stimulation & - & .58 & - \\
\hline Contingent reward & .57 & - & - \\
\hline Idealised influence & .54 & - & - \\
\hline Inspirational motivation & .52 & - & - \\
\hline Idealised influence & .53 & - & - \\
\hline Inspirational motivation & .51 & - & - \\
\hline Idealised Influence & .50 & - & - \\
\hline Trust & .47 & - & - \\
\hline Trust & .42 & - & - \\
\hline Individual consideration & .41 & - & - \\
\hline Individual consideration & .39 & - & - \\
\hline Exception (passive) & - & -.63 & - \\
\hline Exception (passive) & - & -.54 & - \\
\hline Laissez faire & - & -.50 & - \\
\hline Exception (passive) & - & -.47 & - \\
\hline Exception (active) & - & - & .77 \\
\hline Exception (active) & - & - & .63 \\
\hline Exception (active) & - & - & .61 \\
\hline Exception (active) & - & - & .57 \\
\hline Alpha & .90 & .69 & .75 \\
\hline Total explained variance $(\%)$ & 38 & - & - \\
\hline
\end{tabular}

TABLE 2-A1: Internal consistency of subscales of the TCl (short version).

\begin{tabular}{lccc}
\hline TCI (Facet scale) & \multicolumn{3}{c}{ Internal consistency } \\
\cline { 2 - 4 } & Items $(\boldsymbol{n})$ & $\mathrm{M}(\boldsymbol{r})$ & Alpha \\
\hline SD-responsibility & 5 & .21 & .58 \\
SD-purposefulness & 2 & .14 & .25 \\
SD-resourcefulness & 2 & .14 & .24 \\
SD-self-acceptance & 2 & .40 & .57 \\
SD-congruent second nature & 4 & .06 & .18 \\
CO-social acceptance & 3 & .14 & .32 \\
CO-empathy & 1 & - & - \\
CO-helpfulness & 3 & .07 & .18 \\
CO-compassion & 8 & .20 & .67 \\
ST-self-forgetful & 14 & .16 & .58 \\
ST-transpersonal identification & 7 & .13 & .68 \\
ST-spiritual acceptance & 11 & .11 & .60 \\
\hline
\end{tabular}

M, mean; TCI, Temperament and Character Inventory; SD, self-directedness; CO, cooperativeness; ST, self-transcendence. 